\title{
Repression at the Ballpark: Sport, Socialization, and the Birth of a New Stadium Etiquette
}

\author{
Joel Nathan Rosen ${ }^{1}$ and Debra Wetcher-Hendricks ${ }^{2}$
}

This article explores the construction, implementation, and enforcement of behavioral codes in Major League Baseball's ballparks. A qualitative and quantitative examination of this issue suggests that such codes do not exist to maintain safety and legality, but to create an ideal type. We investigate the dichotomy between evidence suggesting that today's ballparks are safer and more fanfriendly now than ever before and the expectations of well-mannered spectators in this most popular arena. We contend that ballpark regulations are part of a broader effort on the part of elites to reign in a supposedly wayward populace, imposing high-culture rules of decorum and redefining the boundaries of personal autonomy. [Article copies available for a fee from The Transformative Studies Institute. E-mail address: journal@transformativestudies.org Website: http://www.transformativestudies.org (C2013 by The Transformative Studies Institute. All rights reserved.]

KEYWORDS: Baseball, Spectators, Social Control, Sociological Imagination.

And now a word from your local jaundiced cynic. Reason and the Human Race by and large is an oxymoron. When the top of the bell curve goes to a baseball stadium and boos the well-executed play of the rival team that would be cheered if the home team made it, is there any question that the majority of humans are demented? —respondent posting on Goosing the Antithesis, 2006

\footnotetext{
${ }^{1}$ Joel Nathan Rosen, Ph.D., is the author of The Erosion of the American Sporting Ethos: Shifting Attitudes Toward Competition and From New Lanark to Mound Bayou: Owenism in the Mississippi Delta. He is also author and co-author of several book chapters and journal articles, and the co-editor of Reconstructing Fame: Race, Sport, and Evolving Reputations. Address correspondence to: Joel Nathan Rosen, Moravian College, 1200 Main Street, Bethlehem, Pennsylvania 18018; e-mail: jrosen@moravian.edu.

${ }^{2}$ Debra Wetcher-Hendricks, Ph.D., has authored Analyzing Quantitative Data: An Introduction for Social Researchers and has presented her analyses of statistical models in academic journals and at conferences. She received recognition in recent editions of Marquis Who's Who in America, Who's Who Among American Women, and Who's Who in the World.
} 